\title{
Carotenoid-glycoprotein of Sarcina flava Membrane
}

\author{
By D. THIRKELL AND M.I.S. HUNTER \\ Department of Biochemistry, Bute Medical Buildings, St Andrews, Fife
}

(Accepted for publication 28 June 1969)

\section{SUMMARY}

The carotenoid-glycoprotein isolated from the membranes of Sarcina flava by using synthetic detergents was not resolved into subfractions. It was resistant to extremes of heat and $\mathrm{pH}$ value. The peptide moiety carried little net charge and the carotenoid was not easily released.

\section{INTRODUCTION}

All of the carotenoid in Sarcina flava is localized in the membranes (Strang, 1968). Two general methods are available for membrane solubilization: the use of synthetic detergents (Salton \& Netschey, 1965; Salton, 1967a,b) and prolonged ultrasonic treatment (Salton, 1967a). The use of synthetic detergents has been studied and nonionic detergents found to be the most effective. Most carotenoproteins studied have been of invertebrate origin (Fox, 1955; Cheesman, 1958; Cheesman, Lee \& Zagalsky, 1967). The link between carotenoid and protein, in these instances, is easily broken and a total recovery of carotenoid made. Since the carotenoid-glycoprotein from the membranes of $S$. flava is associated with carbohydrate and protein (Thirkell, Hunter, Crawford \& Fracassini, 1969), the carotenoid may be glycosidically bound to carbohydrate. Such a situation exists in Mycobacterium phlei (Hertzberg \& Jensen, 1967). The present work was undertaken to study some of the properties, particularly the nature of the bonding of carotenoid, of a detergent-solubilized membrane fraction from S. flava.

\section{METHODS}

Growth and harvesting of bacteria, preparation and solubilization of the membrane: Sarcina flava (NCTC 7503) membranes were prepared as previously reported (Thirkell et al. 1969). Solubilization was achieved by repeated extractions with either I \% (v/v) Lubrol L (I.C.I. Ltd.) or Crillet I (Croda Ltd.), both non-ionic polyoxyethylene derivatives. The solubilized material was exhaustively dialysed against tap water and then distilled water, and the carotenoid-glycoprotein purified by repeated ammonium sulphate precipitation.

Attempted resolution of Crillet $\mathrm{r}$ solubilized carotenoid-glycoprotein. Three techniques were used: (a) Electrophoresis in free buffer film. Separation was attempted on a vertical flow machine with buffers of different ionic strengths and with $\mathrm{pH}$ values ranging from 3.9 to 8.6 . The material was exhaustively dialysed against the buffers for at least $48 \mathrm{hr}$ before being pumped into the machine; $(b)$ Sephadex gel filtration. Concentrated material was applied to columns $(26 \times \mathrm{I} \cdot 5 \mathrm{~cm}$.) of Sephadex G-Ioo and of

Vol. 58, No. 2, was issued 23 December 1969 
G-200 and the columns were developed with $0.1 \%$ (w/v) $\mathrm{NaCl}$. Fractions were collected on a Central Ignition fraction collector; $(c)$ ultracentrifugation. The sedimentation patterns of the material in distilled water were studied on the ultracentrifuge for up to $2 \mathrm{hr}$ after it had reached top speed (59,780 rev./min.).

Examination of Lubrol L solubilized carotenoid-glycoprotein. (a) Effect of heat and $\mathrm{pH}$ value on the absorption spectrum. The absorption spectrum was determined over a range of temperatures (15 to $\left.100^{\circ}\right)$ and $\mathrm{pH}$ values $(4 \cdot 0,7 \cdot 0,10 \cdot 0) ;(b)$ effect of heat on optical rotation. Optical rotation was studied over a temperature range of 18 to $78^{\circ}$; (c) amino acid analysis. A sample was freeze-dried for $36 \mathrm{hr}$ and hydrolysed in a sealed tube with $6 \mathrm{~N}-\mathrm{HCl}$ at $120^{\circ}$ for $24 \mathrm{hr}$. The hydrolysate was made acid free and applied to a Technicon automatic amino acid analyser; $(d)$ attempts to release free carotenoid. (I) Partition with an equal volume of ether, (2) dilution with an equal volume of acetone and ether extracted (Cheesman, 1958), (3) made $4 \mathrm{M}$ with respect to urea, stirred ( $12 \mathrm{hr}$ ) and ether extracted, (4) made $4 \mathrm{M}$ with respect to urea and $\mathrm{I} \%$ $(\mathrm{v} / \mathrm{v})$ with respect to thioglycollic acid, stirred ( $12 \mathrm{hr}$ ) and ether extracted, (5) carotenoid-glycoprotein titrated with either $0 \cdot \mathrm{IN}-\mathrm{HCl}$ or $0 \cdot 1 \mathrm{IN}-\mathrm{NaOH}$ to give samples at $\mathrm{pH}$ $4 \cdot 3,5 \cdot 3,7 \cdot 0,8 \cdot 9$, I I.8 and ether extracted, (6) boiled for I $5 \mathrm{~min}$. and ether extracted, (7) material saponified with $10 \%(w / v)$ methanolic $\mathrm{KOH}$ up to 7 days and ether extracted, (8) digestion with papain. The solution was made $0 \cdot I \mathrm{M}$ with respect to phosphate buffer ( $\mathrm{pH} 7 \cdot 6$ ), $5 \mathrm{mM}$ with respect to EDTA (chelation of metal ions), $\mathrm{I} \cdot 0 \mathrm{mM}$ with respect to cysteine (enzyme -SH groups maintained in the reduced form) and $1 \%(w / v)$ with respect to papain. Digestion was at $40^{\circ}$ in the dark in an atmosphere of nitrogen. Two recharges of EDTA + cysteine + papain were made at $5 \mathrm{hr}$ intervals and the digestion then left overnight. The digest was extracted with ether until the ether phase was colourless. The total etherial extract was dried over anhydrous sodium sulphate, taken to dryness at $25^{\circ}$ and tested for the presence of carotenoid (spectrum), carbohydrate (Whistler \& Wolfrom, 1962) and peptide (amino acid analysis).

\section{RESULTS}

Resolution. With electrophoresis in free buffer film, no resolution was achieved in any system. The carotenoid-glycoprotein did not appear to be charged at any $\mathrm{pH}$ value. No resolution was achieved with Sephadex and on the ultracentrifuge a single symmetrical peak was seen after I hr. These results suggest that a single molecular species had been solubilized.

Table I. Carotenoid-glycoprotein of Sarcina flava membrane: relative concentrations of amino acids present

$\begin{array}{lrlr}\text { Amino acid } & (\%)^{*} & \text { Amino acid } & \begin{array}{r}(\%) \\ \text { Alanine }\end{array} \\ \text { Aspartic acid } & 9.66 & \text { Lysine } & \text { trace } \\ \text { Glutamic acid } & 8.73 & \text { Ornithine } & \text { trace } \\ \text { Glycine } & 7.98 & \text { Phenylalanine } & 6.73 \\ \text { Histidine } & 9.78 & \text { Serine } & 10.35 \\ \text { Isoleucine } & 5.30 & \text { Threonine } & 6.04 \\ \text { Leucine } & 8.19 & \text { Tyrosine } & 4.00 \\ & 14.20 & \text { Valine } & 9.04\end{array}$

\footnotetext{
* Amino acid analysis could not be calculated on a dry weight basis since only drying in a vacuum oven at $85^{\circ}$ for 4 days will remove all the water associated with the detergent (checked by infrared spectroscopy). Such treatment partially degrades the samples.
} 
Spectra. The $\lambda_{\max }$ were 226, 276, 282, 297, 416, 444 and $474 \mathrm{~m} \mu$. The peaks in the visible region are similar to those given by the free pigments of Sarcina flava in organic solvents (Thirkell, Strang \& Chapman, 1967). This suggests that any binding of carotenoid to other molecules does not alter the main chromophore (unlike the situation with carotenoproteins of invertebrates). The peaks at 276 and $282 \mathrm{~m} \mu$ are due to detergent and aromatic amino acids and that at $226 \mathrm{~m} \mu$ to peptide bonding. No change in $\lambda_{\max }$. or peak heights was detected over the range of temperature or $\mathrm{pH}$ value studied, and prolonged boiling did not cause precipitation (mutual stabilization of components, Cheesman et al. 1967).

Optical rotation. No change was detected suggesting that no alteration in the secondary or tertiary structure of the peptide had occurred.

Amino acid composition. The results are shown in Table I.

Attempted release of free carotenoid. The findings are summarized in Table 2. When the effects of urea or urea + thioglycollic acid were examined on the ultracentrifuge, equilibrium patterns were produced. Thus, no conclusions could be drawn as to whether a split into smaller subunits had occurred.

Table 2. Carotenoid-glycoprotein of Sarcina flava membrane: attempts to release free carotenoid from the complex

\begin{tabular}{|c|c|}
\hline Method & Result \\
\hline $\mathbf{I}$ & No release \\
\hline 2 & No release \\
\hline 3 & No release \\
\hline 4 & No release \\
\hline 5 & No release \\
\hline 6 & No release \\
\hline
\end{tabular}

7

8
Some carotenoid released after 6 days.

Pigment release

Comment

Association through a definite type of bonding rather than a loose non-specific association.

Carotenoid bound in a manner different to that found in invertebrate carotenoproteins which are split by this method, after which $100 \%$ of the carotenoid is extractable into ether (Cheesman et al. 1967). The effect of acetone is to denature the protein/peptide and thus the integrity of the tertiary structure of this is not necessary for the bond.

Hydrogen bonding not involved.

Hydrogen bonding not involved; split of any S-S bridges in the protein/peptide moiety does not aid pigment release.

Electrostatic binding not involved.

(i) Hydrogen bonding or $\pi-\pi$ electron interactions not involved since the thermal energy supplied should be in excess of that required to break such bonds. (ii) No precipitation occurred which suggests that the components of the complex mutually stabilize each other.

Suggests that the type of bond ruptured is very weakly alkali labile.

A substantial amount of pigment was released into the ether phase; analytical tests showed that it was not free carotenoid but that it was still associated with carbohydrate, a short peptide and detergent. The effect of papain was that it decreased the peptide to a length which made some of the material preferentially ethersoluble rather than water-soluble.

\section{DISCUSSION}

The solubilized membrane fraction of Sarcina flava appears to be a single molecular species. The amino acid analysis revealed little or no basic amino acids and a very high ammonia peak suggests that most, if not all, of the dicarboxylic amino acids may be 
in the amide form. This would explain why no charge was noticeable during electrophoresis in free buffer film, why the authors could not obtain any reasonable titration curve for the material and why it did not migrate from the origin on disc-gel electrophoresis. The fraction is extremely stable to extremes of temperature (up to $100^{\circ}$ ) and $\mathrm{pH}$ value ( $\mathrm{pH} 4$ to $\mathrm{ro}$ ). Release of free carotenoid is difficult to achieve indicating that the bonding is covalent (glycosidic?). Papain digestion produced smaller units which became ether-soluble, but further degration of these subunits would be required to identify the molecules involved in the links between the components of the complex. The carotenoid-glycoprotein studied was rich in detergent. To what extent the presence of detergent influenced these results cannot be determined since it is impossible to remove all traces of the detergent from the material.

We thank I.C.I. Ltd. and Croda Ltd. for gifts of detergent samples. D. T. is grateful to the Science Research Council for financial support and M. I. S. H. is in receipt of a Science Research Council grant.

\section{REFERENCES}

CheEsman, D. F. (1958). Ovorubin-a chromoprotein from eggs of the gastropod mollusc-Parmacea canaliculata. Proc. R. Soc. B 149, 571.

Cheesman, D. F., Lee, D. F. \& Zagalsky, P. F. (1967). Carotenoproteins in invertebrates. Biol. Rev. 42, 131 .

Fox, D. F. (1955). Animal Biochromes. Cambridge: Cambridge University Press.

HertZBerg, S. \& Jensen, S. L. (1967). Bacterial carotenoids. XX. The carotenoids of Mycobacterium phlei, strain vera 2. The structures of the phlei xanthophylls-two novel tertiary glucosides. Acta chem. scand. 21, 15.

Salton, M. R. J. (1967a). Structure and composition of bacterial membranes. Protides biol. Fluids I5, 279.

Salton, M. R. J. (1967b). Bacterial membranes. In Specificity of Cell Surfaces, Ed. by B. Davis and L. Warren. New Jersey: Prentice-Hall Inc.

Salton, M. R. J. \& Netschey, A. (1965). Physical chemistry of isolated bacterial membranes. Biochim. biophys. Acta 107, 539.

Strang, R. H. C. (1968). Some investigations into the Sarcina bacteria. Ph.D. Thesis, St Andrews University.

Thirkell, D., Strang, R. H. C. \& Chapman, J. R. (1967). The pigments of S. flava: a new series of $\mathrm{C}_{50}$ carotenoids. J. gen. Microbiol. 49, 157.

Thirkell, D., Hunter, M. I. S., Crawford, J. \& Fracassini, A. S. (I969). The effect of synthetic detergent on the determination of the molecular weight of a carotenoid glycoprotein from Sarcina flava. J. gen. Microbiol. 56, 109.

Whistler, R. L. \& Wolfrom, M. L. (1962). Methods in Carbohydrate Chemistry, vol, 1, p. 388. New York and London: Academic Press. 